\title{
The Muslim South in the Context of the Thai Nation
}

\author{
Robert B. Albritton
}

The years since 2004 have been marked by a level of insurgency in the southern region of Thailand unknown for decades. An accurate perspective on this conflict requires a deeper understanding of differences between the Buddhist and Muslim Thais of the region than has been evident in public and academic discourse. This study utilizes data from a survey taken in 2006, of attitudes and political orientations across all regions of Thailand, including an independent sample of the southern region. The data indicate that southerners are different from the rest of Thailand, whether Buddhist or Muslim; that Malay-speaking Muslims are different from other Muslims; and that sympathy for the insurgency lies not in religion, but in defending practices associated with loyalty to specific forms of Malay culture that characterize the region.

KEYWORDS: cultural assimilation, insurgency, Malay identity, social cleavages, southern Thailand, unconventional participation

aily accounts of assassinations of local police, soldiers, religious leaders, and other civilians in southern Thailand document a level of insurgency beyond other regions of Southeast Asia and one that has not been duplicated in Thailand for over thirty years. A history of tensions and conflicts in Thailand's Deep South can be traced back more than 100 years; however, a trend of escalating violence has become more apparent in recent years. During the ten years from 1993 to 2004 , there were 2,593 incidents of political violence. Only 29 percent of these incidents occurred during 1993 to 2003, and 71 percent $(1,841)$ took place in 2004 (including January of 2005). Targets of southern violence are not traditional subjects of the historic separatist movement, that is, government human resources and public installations. When looking at the patterns and tactics of operations in almost daily attacks, it is noticeable that the most frequent tactics, now, are assassinations, shootings, 
even beheadings, followed by bombs and arson attacks on temples, schools, and government buildings. The new insurgency seems oriented less toward political separatist movements of the past, and more toward renewed efforts to secure autonomy of Malay culture (which includes Islam) within the Thai state. ${ }^{1}$ Thus, the new insurgency is different from that of the past, although it appears superficially similar.

Militant separatist movements have existed at least since the early 1970s, in opposition to draconian Thai programs to suppress not so much Islam as the cultural traditions, particularly use of Malay language as a language of instruction in Islamic schools, and a general effort to assimilate forcibly the Malay-speaking provinces. Throughout several decades, these organizations launched attacks, primarily on infrastructure, and engaged in a generalized program of limited armed resistance. There are also a substantial number of smaller groups and criminal gangs that engage in contract killings and extortion. These latter groups are often lumped with the separatist movements in the public mind, even though they have little or no strictly political agenda.

Coincident with the firmer establishment of democracy during the late 1980s, identification with separatist movements declined dramatically, until some observers estimated that by 1990 , only $300-500$ persons were actively associated with these movements (Abuza 2003, 78). Despite these programs of insurgency, many Muslims in southern Thailand have come to view political democracy as a positive channel for their aspirations. Ibrahim Syukri even argues that the Malay people have a democratic history in Patani (Syukri 2005).

The movement of the radical Islamists preys upon the vulnerability of youth whose futures are constrained by poverty and a lack of opportunity for a better life. Following the infamous attacks throughout the Malay-speaking provinces on April 28, 2004, the military and police uncovered printed materials in Jawi titled Berjihad di Pattani [Struggle for Pattani], in which distorted versions of the Koran and erroneous interpretations of orthodox Islam prescribed a program of radical insurgency as a religious duty for youth. Accounts also surfaced of radical teachers who conducted séance-like meetings at which a drink was served that was supposed to make its consumers invulnerable to bullets. At the April 28, 2004, attacks and occupation of the Krue Se mosque in Pattani, roughly half the youths threw themselves at heavily armed troops either without weapons or carrying only knives (McCargo 2008, 39,138).

Daily assassinations of soldiers, police, teachers, and community officials have also destabilized the life and ordinary activities of southern people. Buddhists from other parts of Thailand are reluctant to ac- 
cept jobs as teachers, medical staff, or administrative officers in this region, and Buddhists in the South, in general, feel threatened enough to demand military and police protection, if they do not simply arm themselves or leave the region altogether (McCargo 2009a, 8-9; McCargo 2009b, 14). Martial law has again been imposed on the Malay-speaking provinces, but this, of course, conveys an air of military occupation for the dominant Malay-speaking majority. Correspondingly, tensions have arisen between Buddhists and Muslims; ironically, many Buddhists feel that the government caters to the Malay-speaking majority, thereby ignoring interests of Buddhists.

Even after the September 19, 2006, coup, the government continues to respond with what can only be called inept action. Bangkok officials, press, and public have little understanding of or appreciation for the Malay-speaking Muslim population. Military sweeps have netted hundreds of innocent citizens, as well as members of Parliament, who have been charged with abetting the militancy. Efforts to apply a lawenforcement model have been marred by indiscriminate arrests and the assassination of an attorney who was defending persons arrested and held without charge for months. Underlying government approaches is also an assumption, shared by many Thai intellectuals, that the current violence is totally related to historic discontent and that the ideology of political Islam is subject to ameliorative treatment. Nevertheless, successive governments have ignored (and therefore rejected) recommendations of the National Reconciliation Commission for educational instruction in Malay (the language spoken in the home by a majority in three of the provinces) and for greater use of Malay in bureaucratic transactions in the Malay-speaking area.

Insurgencies can, of course, be conducted by a relatively small number of dedicated revolutionaries. Islamic leaders in southern Thailand emphatically reject the radical interpretation of Islam. Most devout Muslims in the region hold the view that Thailand grants all essentials necessary for Muslim life: freedom to practice their religion, political representation, and governance of domestic relations under sharia or Islamic law. This accommodation has left the number of adherents of radical Islam in a minority. Furthermore, although southern Thai Muslims do identify ethnically as Malay, they do not think of themselves as related to the Malaysian state, even though insurgents take refuge in the northern Malaysian states that have elected Islamic governments. What is not known is the degree of sympathy with these movements among the local population. This is the critical issue for the politics of the South and, in a small beginning, the topic of this study. 
Discourses surrounding the causes of violence in the South vary dramatically. Scholars often rely on historical explanations linking the current violence to the separatist movements of militant rebel organizations-Pattani United Liberation Organization (PULO), the smaller but more radical Berisan Revolusi Nasional (BRN, more specifically the BRN-Coordinate), and a larger coordinating group known as BERSATU (United Front for the Independence of Pattani) (Satha-Anand 2005). New organizations without linkages to the historic conflict have appeared on the scene-Geragan Mujahideen Islam Pattani (GMIP); the Runda Kampulan Kecil (RKK), an armed wing of the BRN; and the very new South Warriors of Valaya (SWV), with origins in Indonesia via Malaysia.

In contrast, Nithi Aeosrivongse (2005) argues that traditional separatist movements only give public support and praise from the sidelines for the actions that he sees as representing a peasant revolt. In this interpretation, the recent rise in insurgency is not related to traditional political separatism. Previous movements, he argues, were led by traditional elites, but these elites, including religious elites-the toh krue or toh imam - have publicly refused to identify themselves with the insurgents. For Nithi, the revolt arises from differences between peasants' need for a more just distribution of resources and the program of a "developmental" state.

Neither of these perspectives is consistent with the abrupt rise of terrorist violence beginning after 2000. Srisompob Jitpiromsri and Panyasak Sobhonvasu (2005) show that historical trajectories are inconsistent with recorded incidents of terrorist violence that rose precipitously from 84 in 2003 to 1,843 in 2004. Furthermore, political separatism does not usually justify indiscriminate assassinations in which "ordinary people," rather than officials, are the primary victims. They argue that relations with international terrorist groups are unambiguous and that what distinguishes the current insurgency from the history of separatist movements is the political ideology of a radical Islamic state.

This perspective, from the affected area, contrasts sharply with the report of the International Crisis Group and US State Department Country Reports that find the insurgency driven by local issues. Jitpiromsri and Sobhonvasu argue that Al-Qaida operatives have used Thailand as a base of operations since the mid-1990s and that many of the separatist insurgents have received training in Libya, Syria, and Afghanistan and have fought with the Afghan mujahideen there. Known Al-Qaida and Jemaah Islamiyah operatives, such as Hambali, and some of the Bali bombers sought refuge in southern Thailand. Foreign fighters, Indonesians thought to be associated with Jemaah Islamiyah, were killed 
among those who died at the Krue Se mosque in 2004. This latter view suggests that the spark for an abrupt surge in violence was the introduction of radical Islam into the region (Jitpiromsri and Sobhonvasu, 2005).

Finally, Marc Askew (2007) elaborates on a widely held view that much of the violence is a calculated political strategy by criminal gangs and political overlords to destabilize the region. Contrary to conventional practice of attributing the insurgency to policies of Thaksin Shinawatra, Askew argues that such interpretations are essentially political ploys by Thaksin's opponents to demonize the Thai Rak Thai (TRT) regime, including the Wadah faction, in order to reassert Prachadhipat Party dominance in the region. ${ }^{2}$ All these scenarios pit the cultures of Thai Buddhists against Thai Muslims, even though there appears to be little conflict between Buddhists and Muslims in other parts of Thailand.

\section{Buddhists and Muslims in Southern Thai Politics}

This study provides data challenging the conventional wisdom that Buddhists and Muslims represent fundamental political cleavages based upon cultural orientations associated with Buddhism and Islam. The data show that the more fundamental cleavages are not essentially religious, but ethnocultural, represented by orientations to Malay or Thai culture and identity, as indicated by the language spoken in the home. It is the culture, rather than religion, that differentiates the southern Thai population. Although Islam provides appropriate symbols for political resistance to government, culture represents more fundamental and difficult issues for national identity. In the South, at least, the language of the home is the fundamental marker of shared culture among southern Thai Muslims. Muslims who speak Thai (rather than Malay) in the home, for example, are significantly more assimilated into the Thai state (Albritton et al. 1996; Albritton and Prabudhanitisarn 1997).

The evidence indicates that whatever cleavages exist are not related specifically to Islam and Buddhism as much as they are related to a cultural identity that serves as a wedge between the two cultures. Thus, it is inaccurate to describe insurgencies as representative of "Muslim" opposition to Thai governance of the southern region. Satun, for example, a province that is heavily Muslim but Thai-speaking, exhibits little of the unrest that characterizes the other predominantly Muslim provinces. The position taken here, as a hypothesis, is that Muslims are undifferentiated from Buddhists in terms of basic values and orientations, but Muslims 
who speak Thai as the language of the home will differ in fundamental political respects from Malay-speaking residents. The data reported here provide information on cleavages between Buddhists and Muslims in the southern region beginning with fundamental issues of identity and assimilation into the Thai state. Convergence of attitudes across these communities constitutes some evidence of the survivability and sustainability of democratic governance and social harmony in the region.

There are many ambiguities in the literature on political Islam. For example, one report (Tessler 2002) found that personal piety had little impact on attitudes toward democratic government. The gist of these arguments is that attitudes toward government appear to be largely a result of government performance rather than cultural predispositions (as argued in Mishler and Rose 2001). On the other hand, another author (Arjomand 1995) suggests that religious radicalism is less likely when states are clearly Islamic in their orientation. Correspondingly, this study examines evaluations of government performance to determine if they are distinguishable between Buddhists and Muslims.

The study considers the four predominantly Muslim provinces (Satun, Narathiwat, Pattani, and Yala) in Thailand and a largely Muslim contiguous province (Songkla) to determine characteristics of the populations in these provinces: The level of democratic consolidation represented by support for democracy and pluralist institutions, the level of trust in government on the part of Muslim (more specifically the Malay-speaking Muslim) populations of Thailand, impacts of religion (specifically self-professed piety) on orientations to government and society, and a variety of other items of interest (political efficacy, traditionalism, and socioeconomic status) are analyzed both within the region and in comparison with the rest of Thailand. In addition to the specifics of the concepts noted above, the data should paint a picture of political stability (or instability) in the region with implications for the threat of irredentism to the Thai nation. What is unique about the data is information on support for radical Islam in the form of affinity for radical groups and issues of identity and assimilation as Thais in the population of the insurgent area.

\section{The Role of Cultural Identity and Radical Islam}

The data on the five southern provinces permit deeper explorations of cultural identity in the region. There are, essentially, both objective and subjective indicators of cultural diversity that transcend a superficial 
dichotomy between Buddhist and Muslim citizens. Previous research reveals substantial political cleavages, not only between Buddhists and Muslims, but also between Malay-speaking Muslims and Muslims who speak Thai in the home (Albritton et al. 1996). Satun is virtually a Thaispeaking Muslim province and the minority Muslim population in Songkla is primarily Thai-speaking. The consequence of this cleavage within the Muslim community of the Deep South is that Thai-speaking Muslims are generally far more assimilated than their Malay-speaking counterparts. It is not a coincidence that Satun experiences little of the insurgency common to Narathiwat, Pattani, and Yala or that orientations of Songkla Muslims are quite different from those of the Malayspeaking provinces. In order to analyze this dimension of identity in these provinces, the data have been refined to indicate respondent identification as Buddhists, Thai-speaking Muslims, or Malay-speaking Muslims.

A more profound measure of identity, however, comes from a question administered only to respondents in the five southern provinces. Respondents were allowed to indicate their subjective identity in response to a question asking for their primary identity as "Thai," "Malay," "Muslim," or "Buddhist." The purpose of the question was to ascertain whether individuals derive their identities primarily from identification with the nation, ethnicity, or, as most often supposed, a primary religious identification.

It is equally important to note that provincial boundaries are neither useful nor constant, historically. Initially, within Pattani, there were, historically, seven provinces (Pattani, Nong Chik, Yaring, Saiburi, Yala, Raman, and Rangae). Even after these provinces were reduced to four-Pattani, Yala, Saiburi, and Bangara (later Narathiwat) under Rama II (1906), the original divisions still provide the basis for conflicting political rivalries. In fact, all Muslims in these provinces live in a contiguous area whether they speak Malay or Thai in the home. Because Muslim identity is based upon three pillars, nayu (race), baso (language), and Islam, the primary differentiating indicator of culture among southern Thai Muslims is language spoken in the home, Thai or Malay. Language as a cultural marker thus indicates a cultural cleavage among Muslims far more important than the provincial boundaries. In Songkla and Satun, for example, most Muslims speak Thai in the home; this differentiates them culturally from those, residing in a contiguous area, who speak primarily Malay. Although there are Muslims in the predominantly Malay provinces who speak only Thai, they, too, tend to reside in a different cultural milieu from that of 
their Malay-speaking neighbors. One of the most important sources of conflict in southern Thailand is this distinction between Thai-speaking and Malay-speaking Muslims and, therefore, ability to assimilate, as is borne out in the analysis. ${ }^{3}$

\section{Methodological Approach to the Study of Radical Islam in Southern Thailand}

The study utilizes data from a sample of 1,500 respondents on voter lists, from the five Muslim provinces of Narathiwat, Pattani, Satun, and Yala, and from a fifth province, Songkla, where the population is over one-third Muslim, but generally Thai-speaking. Analysis indicates that this was a representative sample conforming to gender and age divisions of the census. Substitutions of missing respondents were made by a randomizing procedure for persons on the voter lists lying on either side of the chosen respondent. To control for systematic gender bias, substitutions were of the same gender as the chosen respondent. When this method was applied in a 2002 national sample, the response rate was over 92 percent without substitutions. All interviews were face-toface. A probability sample based upon this strategy does not require stratification and should produce a highly representative sample with a sampling error of plus or minus 4.5 percent.

This study has a significant bonus: The survey was taken in conjunction with a national study for the Asian Barometer using the same questionnaire (with the exception of sixteen questions added to the southern interview schedule). This coincidence allows comparisons of attitudes in the Deep South changwat (provinces) with those found in the rest of the Thai nation. ${ }^{4}$

Survey research in an area of insurgency invariably produces problems of sampling. Three voter units (precincts) in Narathiwat fell within so-called red zones where not even government officials were allowed. This coincidence accounted for a loss of about twenty respondents; substitution of adjoining voting units was the method of correction.

Do persons residing in the southernmost region of Thailand differ in significant ways from their fellow citizens in the rest of Thailand? In order to answer this question, the study combines the regional survey described above with a contemporaneous 2006 national survey conducted by the King Prajadhipok's Institute $(N=1,546)$. So that all respondents have a roughly equal probability of being interviewed, respondents from Narathiwat and Songkla from the national sample $(N=$ 
105) were replaced with the 1,500 respondents from the oversample. The merged data thus contain 1,441 respondents from the national sample and 1,500 from the five southern changwat. This procedure permits comparisons between these changwat and the rest of Thailand.

The data presented here provide answers to several important questions concerning cleavages between Buddhists and Muslims in southern Thailand and permit inferences that answer several questions:

1. Are the residents of the five southern Thai provinces different from their fellow citizens in the rest of Thailand?

2. Do Buddhists and Muslims differ in basic values, but also in their identification with the Thai state?

3. Are there differences in the level of assimilation among Muslims, that is, between those who speak Malay as the language of the home and those who speak Thai?

\section{Regional Cleavages Between the Five Southern Provinces and the Rest of Thailand}

Significant differences do exist between residents of the southern provinces and the rest of Thailand in fundamental orientations to society (Table 1). Respondents in the southern provinces, for example, are far less likely to trust people than those from other parts of Thailand. Only 19.3 percent, for example, say that most people can be trusted, and less than half of those living in the Deep South have substantial trust in people with whom they interact frequently. Family values seem to be held in common; there are few significant differences. Overall, however, respondents from the Deep South appear less deferential to authority, and, perhaps, a bit more tolerant of conflict, although deference to authority by both groups is well below 40 percent.

More important is the perception of safety in the respective towns or villages. Residents of the southern provinces understandably feel less safe and secure than those in the rest of Thailand. When asked about safety compared to previous periods, 82.2 percent of respondents from the rest of Thailand say that they feel "more safe" or "about the same," but over one-third of southern respondents indicate that they feel "less safe" and only 10.2 percent say "about the same." These higher levels of insecurity may help to explain some sources of attitudes in the Thai population as a whole, particularly in the five southern provinces. Significant declines in feelings of security in the latter 


\begin{tabular}{|c|c|c|c|c|}
\hline \multicolumn{2}{|l|}{ Items } & $\begin{array}{l}\text { Rest of } \\
\text { Thailand }\end{array}$ & $\begin{array}{c}\text { Five } \\
\text { Changwat }\end{array}$ & $P<$ \\
\hline \multicolumn{2}{|c|}{ Most people can be trusted } & 47.8 & 18.8 & .000 \\
\hline \multicolumn{2}{|c|}{ Trusting other people with whom you interact } & 55.8 & 40.9 & .000 \\
\hline \multicolumn{2}{|c|}{$\begin{array}{l}\text { Even if a parent's demands are unreasonable, } \\
\text { children should still do as they are asked }\end{array}$} & 52.9 & 39.0 & .000 \\
\hline \multicolumn{2}{|c|}{$\begin{array}{l}\text { A student should not question the authority of } \\
\text { a teacher }\end{array}$} & 51.5 & 46.7 & .000 \\
\hline \multicolumn{2}{|c|}{$\begin{array}{l}\text { A person should not insist on his own opinion if } \\
\text { coworkers disagree }\end{array}$} & 67.0 & 71.2 & .000 \\
\hline \multicolumn{2}{|c|}{$\begin{array}{l}\text { For the sake of family, an individual should put } \\
\text { personal interests second }\end{array}$} & 85.2 & 84.5 & .200 \\
\hline \multicolumn{2}{|c|}{$\begin{array}{l}\text { Sometimes one has to follow one's own beliefs } \\
\text { regardless of what people think }\end{array}$} & 69.2 & 64.6 & .106 \\
\hline \multicolumn{2}{|c|}{$\begin{array}{l}\text { We should give up gains in the present for larger } \\
\text { gains in the future }\end{array}$} & 62.1 & 56.3 & .009 \\
\hline \multicolumn{2}{|c|}{ How safe is living in your town or village (safe) } & 13.4 & 32.0 & .000 \\
\hline \multicolumn{5}{|c|}{$\begin{array}{l}\text { How safe is your village compared to a few } \\
\text { years ago }\end{array}$} \\
\hline \multicolumn{2}{|c|}{ Safer } & 45.7 & 10.2 & .000 \\
\hline \multicolumn{2}{|c|}{ Less safe } & 19.6 & 55.9 & .000 \\
\hline
\end{tabular}

pose at least one possible cause of the variation that exists between the two areas.

Differences between the respondents in the border provinces and the rest of Thailand are even more apparent in terms of political attitudes and orientations (Table 2). Most significant are pronounced differences in levels of trust in government institutions. Thailand shows substantial majorities in support of all institutions of government, including political parties. Southern respondents, however, trust only the courts and local governments by a majority. In most respects, these data indicate significant cleavages between the South and the rest of Thailand over institutions of the central government.

Table 2 indicates significant differences also in evaluations of government. Southerners tend to see government as more corrupt, much less responsive and egalitarian in its treatment of citizens. Despite the fact that most southern respondents observe a lack of what may be described as "good governance," the data (not reported here) show no differences in perceptions of freedom of speech, ability to join organizations, and opposition to a military government (over 80 percent).

Despite more negative evaluations of government by southern respondents, there are virtually no significant differences between these 
Table 2 Similarities and Differences in Political Orientations and Attitudes Between Respondents in Five Southern Changwat and the Rest of Thailand, 2006 (in percent)

\begin{tabular}{|c|c|c|c|}
\hline Items & $\begin{array}{l}\text { Rest of } \\
\text { Thailand }\end{array}$ & $\begin{array}{c}\text { Five } \\
\text { Changwat }\end{array}$ & $P<$ \\
\hline \multicolumn{4}{|l|}{ Trust in: } \\
\hline Prime minister & 74.0 & 24.7 & .000 \\
\hline Courts & 80.7 & 52.1 & .000 \\
\hline National government & 69.1 & 25.5 & .000 \\
\hline Political parties & 59.7 & 16.2 & .000 \\
\hline Parliament & 67.8 & 32.4 & .000 \\
\hline Civil service & 77.3 & 41.3 & .000 \\
\hline The military & 81.3 & 42.0 & .000 \\
\hline The police & 65.8 & 36.0 & .000 \\
\hline Local government & 78.0 & 50.9 & .000 \\
\hline Newspapers & 54.3 & 40.3 & .000 \\
\hline Television & 70.3 & 52.9 & .000 \\
\hline Election commission & 65.3 & 41.2 & .000 \\
\hline Nongovernmental organizations & 59.2 & 43.5 & .000 \\
\hline Interested in politics & 74.6 & 57.5 & .000 \\
\hline Impact of politics on daily life & 54.2 & 73.6 & .000 \\
\hline $\begin{array}{l}\text { Always support government decisions even } \\
\text { if disagree }\end{array}$ & 51.8 & 30.4 & .000 \\
\hline Voter participation in elections & 95.2 & 93.9 & .176 \\
\hline Freeness and fairness of last national election & 79.4 & 53.8 & .000 \\
\hline All treated equally by government & 59.7 & 47.5 & .000 \\
\hline Government responsiveness & 54.5 & 31.0 & .000 \\
\hline Corruption in national government & 27.2 & 56.7 & .000 \\
\hline $\begin{array}{l}\text { Government should maintain ownership of } \\
\text { state enterprises }\end{array}$ & 84.9 & 19.0 & .000 \\
\hline Satisfaction with the Thaksin government & 84.8 & 42.7 & .000 \\
\hline $\begin{array}{l}\text { Part of the country should be allowed to become } \\
\text { fully separated }\end{array}$ & 7.0 & 18.1 & .000 \\
\hline
\end{tabular}

areas in political participation. Table 2 shows that no significant differences occur in voter participation, and the same holds true for a variety of political participation measures, including attending political rallies, encouraging others to vote for candidates, general assistance to candidates in campaigns, and the ability of respondents to participate in politics. Although southerners claim to be less "interested" in politics, significantly more of them recognize the importance of politics in their daily lives.

There are significant differences in how freeness and fairness of elections are judged in the respective areas. Over 80 percent of Thais outside the insurgency area rate national elections as essentially free and fair. Less than a majority in the five provinces are as positive about the elections process. Southern respondents are, thus, more cynical 
about the political process, even though the conventional wisdom in Thailand holds that elections are "cleaner" in the southern provinces.

Table 2 ends with several indicators of special interest for understanding the pronounced cleavages between the five southern provinces and the rest of Thailand. Differences between these areas in terms of the desirability of maintaining state-owned enterprises are remarkable because of the strikingly large differences in proportions of respondents supporting this policy. Differences in satisfaction with the Thaksin government are not surprising except in the very high levels of overall support (this as late as April 2006) in Thailand as a whole. Even the southern respondents express over 40 percent support for the Thaksin government at a time when Thaksin was perceived as highly unpopular in the southern areas.

One of the most important questions in the survey attempts to measure support for independence or separation of parts of the country. As might be expected, over 90 percent of the rest of Thailand opposes any idea of allowing a part of the country to become fully separated. Even 81.9 percent of the southern sample opposes such an action. It is important to point out, however, this means that nearly one-fifth of the southern respondents support separation from Thailand, a somewhat large proportion of disaffected citizens and a problem for maintaining a united nation.

Why do these cleavages between the five southern provinces and the rest of Thailand in social and political values occur? The superficial explanation given in the media, both Thai and international, is that "of course" this is because of the differences between Muslims in the South and Buddhists in the rest of Thailand. A 1996 study, however, showed that pronounced differences exist between Buddhists in the South and Buddhists in the North, leading to a conclusion that such differences are rooted in regional factors, rather than religious differences (Albritton and Prabudhanitisarn 1997).

Tables 3 and 4 show corresponding patterns of political orientations and values for Buddhists only. The same patterns obtain, but the Deep South is actually more negative toward government and its institutions when Muslims are omitted from the sample. The differences between the southern provinces and the rest of Thailand in orientations toward government are not a function of Malay-Muslim attitudes; the region is even more negative when Muslims are excluded from the sample. Clearly, the region is characterized by a significant degree of alienation from the rest of Thailand not accounted for by the presence of Muslim majorities. Ironically, southern Buddhists tend to be mar- 
Table 3 Similarities and Differences in Social Attitudes and Values Between Respondents in Five Southern Changwat and the Rest of Thailand, 2006, Buddhists Only (in percent)

\begin{tabular}{|c|c|c|c|}
\hline Items & $\begin{array}{l}\text { Rest of } \\
\text { Thailand }\end{array}$ & $\begin{array}{c}\text { Five } \\
\text { Changwat }\end{array}$ & $P<$ \\
\hline Most people can be trusted & 48.2 & 19.3 & .000 \\
\hline Trusting other people with whom you interact & 55.9 & 42.6 & .000 \\
\hline $\begin{array}{l}\text { Even if a parent's demands are unreasonable, } \\
\text { children should still do as they are asked }\end{array}$ & 51.9 & 32.9 & .000 \\
\hline $\begin{array}{l}\text { A student should not question the authority of a } \\
\text { teacher }\end{array}$ & 51.1 & 40.7 & .000 \\
\hline $\begin{array}{l}\text { A person should not insist on his own opinion if } \\
\text { coworkers disagree }\end{array}$ & 67.4 & 71.3 & .000 \\
\hline $\begin{array}{l}\text { For the sake of family, an individual should put } \\
\text { personal interests second }\end{array}$ & 85.7 & 84.6 & .817 \\
\hline $\begin{array}{l}\text { Sometimes one has to follow one's own beliefs } \\
\text { regardless of what people think }\end{array}$ & 69.7 & 61.1 & .031 \\
\hline $\begin{array}{l}\text { We should give up gains in the present for larger } \\
\text { gains in the future }\end{array}$ & 61.9 & 56.1 & .102 \\
\hline How safe is living in your town or village (safe) & 13.0 & 71.4 & .000 \\
\hline \multicolumn{4}{|l|}{$\begin{array}{l}\text { How safe is your village compared to a few } \\
\text { years ago }\end{array}$} \\
\hline Safer & 47.3 & 10.9 & .000 \\
\hline Less safe & 18.2 & 49.7 & .000 \\
\hline
\end{tabular}

Note: This table compares only Buddhists in the Deep South with Buddhists in the rest of Thailand. The data from 2006 confirm the previously cited analysis in 1992 that the source of differences in social values and attitudes is rooted in regional differences, rather than religious or even cultural ones. The data from Buddhists in the five southern provinces are virtually identical to those when Muslims are included in the sample (see Table 1). Whatever these differences, they do not come from differences in religion or Malay-Islamic culture. The one difference observed in these data is that southern Buddhists clearly do not feel as "safe" or that safety has improved in recent years. Given the level of violence directed at the Buddhist population in the insurgent provinces, it is difficult to imagine how it could be otherwise. In virtually all other respects, the data show the same differences between Buddhists in the Deep South and the rest of Thailand in these basic social orientations (Komin 1991).

ginally more likely to support political separation from the rest of Thailand than Buddhists in other parts of the nation.

\section{Social and Political Values of Buddhists and Muslims in Southern Thailand}

Following the work of Komin (1991), a major task is to test ways in which Buddhists and Muslims in the five southern provinces differ in terms of orientations to social and political values in their societies. Table 5 compares these communities on a variety of social attitudes and 
Table 4 Similarities and Differences in Political Orientations and Attitudes Between Respondents in Five Southern Changwat and the Rest of Thailand, 2006, Buddhists Only (in percent)

\begin{tabular}{lccc}
\hline & $\begin{array}{c}\text { Rest of } \\
\text { Thailand }\end{array}$ & $\begin{array}{c}\text { Five } \\
\text { Changwat }\end{array}$ & $P<$ \\
Items & & & \\
Trust in: & 75.6 & 19.9 & .000 \\
$\quad$ Prime minister & 81.2 & 54.4 & .000 \\
$\quad$ Courts & 70.5 & 23.6 & .000 \\
$\quad$ National government & 61.2 & 15.6 & .000 \\
Political parties & 69.1 & 30.7 & .000 \\
$\quad$ Parliament & 78.1 & 47.8 & .000 \\
Civil service & 81.4 & 64.2 & .000 \\
$\quad$ The military & 66.8 & 45.2 & .000 \\
$\quad$ The police & 78.2 & 50.2 & .000 \\
$\quad$ Local government & 54.3 & 48.8 & .000 \\
$\quad$ Newspapers & 70.0 & 67.4 & .000 \\
$\quad$ Television & 67.2 & 41.0 & .000 \\
$\quad$ Election commission & 60.6 & 46.2 & .000 \\
$\quad$ Nongovernmental organizations & 74.6 & 57.5 & .000 \\
Interested in politics & 54.0 & 68.1 & .000 \\
Impact of politics on daily life & 52.3 & 26.8 & .000 \\
Always support government decisions even & & & \\
$\quad$ if disagree & 95.2 & 94.9 & .704 \\
Voter participation in elections & 80.5 & 45.1 & .000 \\
Freeness and fairness of last national election & 60.3 & 45.3 & .000 \\
All treated equally by government & 55.7 & 32.6 & .000 \\
Government responsiveness & 25.1 & 58.0 & .000 \\
Corruption in national government & 84.5 & 19.0 & .000 \\
Government should maintain ownership of & & & \\
state enterprises & 84.8 & 42.7 & .000 \\
Satisfaction with the Thaksin government & 6.8 & 11.1 & .016 \\
Part of the country should be allowed to & & & \\
$\quad$ become fully separated & & & \\
\hline &
\end{tabular}

Note: This table compares only Buddhists in the Deep South with Buddhists in the rest of Thailand.

orientations-particularly in terms of orientations to traditional versus modernist values. The data show, once again, that Buddhists and Muslims in southern Thailand do not differ dramatically in orientations to society. Muslims are more supportive of "traditional" values of authority of parents and teachers; on other items of traditional values, there are no significant differences between Buddhists and Muslims in the five southern provinces. In fact, the data show no significant relationships based on religion among any of the dimensions analyzed, specifically attitudes toward democracy, political efficacy, or political participation. Buddhists and Muslims in southern Thailand, as demonstrated in previous literature, are not different in the political and social values they hold in any meaningful way. 
Table 5 Differences Between Buddhists and Muslims in Social Values in Five Southern Changwat, 2006 (in percent)

\begin{tabular}{lccc}
\hline Items & Buddhists & Muslims & $P<$ \\
\hline $\begin{array}{l}\text { Most people can be trusted } \\
\text { Trusting other people with whom you interact }\end{array}$ & 19.3 & 18.7 & .798 \\
$\begin{array}{l}\text { Even if a parent's demands are unreasonable, } \\
\quad \text { children should still do as they are asked }\end{array}$ & 32.6 & 39.9 & .293 \\
$\begin{array}{l}\text { A student should not question the authority of } \\
\quad \text { a teacher }\end{array}$ & 40.7 & 41.8 & .000 \\
$\begin{array}{l}\text { A person should not insist on his own opinion if } \\
\quad \text { his coworkers disagree }\end{array}$ & 71.3 & 70.6 & .001 \\
$\begin{array}{l}\text { For the sake of the family, an individual should } \\
\quad \text { put personal interests second }\end{array}$ & 84.6 & 84.7 & .940 \\
$\begin{array}{l}\text { Sometimes one has to follow one's own beliefs } \\
\quad \text { regardless of what people think }\end{array}$ & 61.1 & 66.8 & .638 \\
$\begin{array}{l}\text { We should give up gains in the present for larger } \\
\quad \text { gains in the future }\end{array}$ & 56.1 & 56.8 & .880 \\
$\begin{array}{l}\text { How safe is living in your town or village (safe) } \\
\text { How safe is your village compared to a few }\end{array}$ & 71.4 & 66.1 & .005 \\
$\quad$ years ago & & & \\
$\quad$ Safer & 10.6 & 10.0 & .007 \\
$\quad$ Less safe & 49.7 & 58.4 & .007 \\
\hline
\end{tabular}

Note: $N=1,500$.

\section{Cultural Socialization and Experiences with Government}

A second line of inquiry examines the experiences of Buddhists and Muslims in cultural socialization compared to later experiences with government. As noted above, Mishler and Rose (2001) place more emphasis on later socialization experiences, specifically interactions with governments. Table 6 compares the two communities on a variety of cultural orientations, perceptions of corruption at local and national levels, as well as the level of personal experiences with corruption encountered by residents of the southern region as early as 2002 .

These data also support inferences that both cultural socialization and later socialization to government distinguish between Muslim and Buddhist communities of southern Thailand. Two factors call attention in this regard. The first is that although both communities are roughly at the midpoint of a "modernism" scale, Muslim respondents count themselves as less modern and more "rural" in their outlooks on life. Buddhist respondents identify themselves as significantly less "religious" than Muslims-a response that points to a major difference in the social life of the two communities. 
Table 6 Comparisons of Buddhist and Muslim Communities in Five Southern Provinces on Indicators of Cultural Socialization and Interactions with Government, 2001

\begin{tabular}{|c|c|c|c|}
\hline \multirow[b]{2}{*}{ Items } & \multicolumn{3}{|c|}{ Scores ( 1 to 10 scale) } \\
\hline & Buddhists & Muslims & $P<$ \\
\hline How modern (thansamay) would you say you are & 6.05 & 5.33 & .038 \\
\hline $\begin{array}{l}\text { How would you describe yourself and the way you } \\
\text { think about life (chao ban-khon muang) }\end{array}$ & 4.60 & 3.81 & .015 \\
\hline \multirow[t]{2}{*}{ How religious would you say you are } & 6.60 & 7.56 & .003 \\
\hline & \multicolumn{3}{|c|}{ Percentages from Contingency Table } \\
\hline Items & Buddhists & Muslims & $P<$ \\
\hline Respondent has personally witnessed corruption & 4.2 & 14.3 & .009 \\
\hline How corrupt are local government officials (corrupt) & 32.4 & 39.7 & .001 \\
\hline $\begin{array}{l}\text { How corrupt are national government officials } \\
\text { (corrupt) }\end{array}$ & 51.3 & 60.5 & .002 \\
\hline
\end{tabular}

Note: $N=228$. Scores are based on a scale from 1 to 10 , where 1 is the least and 10 is the most.

The second source of cleavage is the consistent sense that Muslims experience more corruption in government and that, therefore, they are more likely to evaluate government officials as corrupt. Clearly, southerners view local government as less corrupt than the national government, a response that suggests relatively more alienation from the central authority. While only about a third of respondents view local government officials as corrupt, over a majority view national officials as corrupt, with Muslims holding such views at over 60 percent. This viewpoint poses problems of legitimacy in the exercise of authority by the central government.

The data indicate that experiences with corruption and belief in the corruption of government officials at both local and national levels are the major forms of socialization that distinguish between the two communities, suggesting that encounters with government have significantly more negative impacts on Muslims than on their Buddhist counterparts. In addition, perceptions of government as, essentially, corrupt go a long way toward delegitimizing government authority, more among Muslims than among Buddhists. Whether these views are merely "perceptions" rather than reality cannot be answered here. For all practical purposes, the subjective reality is at least as important as any objective indicator for defining an oppressed society. 
Table 7 presents the combination of objective and subjective identities with significant results. First, the overwhelming majority of Buddhists (88.7 percent) identify themselves primarily as "Thai," that is, as citizens of Thailand or as Thai ethnicity, rather than as Buddhists. Muslims, by contrast, identify themselves primarily in terms of their religion, Islam (60.6 percent), rather than by association with Malay culture (5.2 percent). Even more significant is the fact that when Muslims are identified as "Thai-speaking" or "Malay-speaking," significant differences in identity emerge between these groups. Only about half of Thai-speaking Muslim respondents identify primarily as "Muslims"; instead, nearly half of all respondents in this category identify primarily as "Thai." By contrast, two-thirds of Malay-speaking Muslims identify themselves primarily as "Muslims," and only slightly over onefourth identify primarily as Thai. Although it is not yet clear whether identification as "Thai" reflects a citizen identification or an ethnic one, the differences are sufficiently significant to assume substantial cleavages between Thai-speaking and Malay-speaking Muslims in terms of how they assimilate into the Thai nation. These identities also translate into attitudes toward the Thai state and whether respondents hold favorable or unfavorable views toward radical Islamic or insurgent movements that affect the five southern changwat. Perhaps the most important findings in Table 7 are the large proportion of Muslims who identify themselves primarily as "Thai" and the fact that Thai-speaking Muslims are considerably more likely to identify themselves in this way than Malay-speaking Muslims.

The data include information on whether respondents are familiar with a variety of personalities and organizations, as well as how they rate these persons as favorable or unfavorable. Although respondents were asked to provide the same information on recognizable people,

\section{Table 7 Comparisons of Objective and Subjective Indicators of Respondent Identity, 2006}

\begin{tabular}{lccc}
\hline & \multicolumn{3}{c}{ Objective Identity (\%) } \\
\cline { 2 - 4 } Subjective Identity & Buddhists & $\begin{array}{c}\text { Thai-Speaking } \\
\text { Muslims }\end{array}$ & $\begin{array}{c}\text { Malay-Speaking } \\
\text { Muslims }\end{array}$ \\
\hline Above all I am Thai & 88.7 & 44.7 & 27.5 \\
Above all I am Malay & 0.9 & 5.0 & 5.1 \\
Above all I am Muslim & 1.5 & 49.7 & 66.7 \\
Above all I am Buddhist & 8.8 & 0.7 & 0.7 \\
\hline
\end{tabular}


parties, and organizations, included in the list are five names generally associated with radical Islamic movements: Al-Qaida, PULO, Jemaah Islamiyah, BRN, and Osama bin Laden. Over 800 respondents professed knowledge or familiarity with each of these items. ${ }^{5}$ There were no significant differences in any of the identity measures in recognition of these subjects.

A factor analysis of the same items on favorable-unfavorable ratings produced intriguing results. Some twenty items factored naturally on five distinct factors. Factor 1 included all of the five items associated with radical Islam noted above; Factor 2 included national or international organizations such as Association of Southeast Asian Nations, the United Nations, Asia-Pacific Economic Cooperation, and the National Reconciliation Commission; Factor 3 was dedicated to two items-Thaksin Shinawatra and Thai Rak Thai; Factor 4 included the other three major political parties-Prachadhipat, Chart Thai, and Mahachon. Based upon this outcome, a score for Factor 1 was recomputed by adding the individual favorable-unfavorable scores for the five items indicating radical Islam.

As might be expected, Muslims in general are significantly more favorable toward each of these items than Buddhists. In addition, there are no significant differences between Thai-speaking Muslims and Malayspeaking Muslims on favorability toward each of these items. The subjective identity measure, however, shows somewhat different results. Table 8 indicates significant differences in evaluations of radical Islamic movements associated with how respondents identify themselves.

\section{Table 8 Respondents' Self-Identification and Evaluations of Radical Islamic Items (1 to 10 scale)}

\begin{tabular}{lccccc}
\hline & \multicolumn{5}{c}{ Above All I Am } \\
\cline { 2 - 6 } Item & Thai & Malay & Muslim & Buddhist & $P<$ \\
\hline Al-Qaida & 3.93 & 5.24 & 4.68 & 2.97 & .000 \\
Pattani United Liberation & & & & & \\
$\quad$ Organization & 3.42 & 4.09 & 4.07 & 2.67 & .000 \\
Jemaah Islamiyah & 3.53 & 4.37 & 4.23 & 3.22 & .001 \\
Berisan Revolusi Nasional & 3.79 & 3.78 & 4.08 & 3.33 & $.267^{\mathrm{a}}$ \\
Osama bin Laden & 3.73 & 5.21 & 5.18 & 3.22 & .000 \\
Overall score in rating radical & & & & & \\
$\quad$ Islamic items as favorable & 17.98 & 23.25 & 21.51 & 14.42 & .000 \\
\hline
\end{tabular}

Note: a. The nonsignificance of this item at a .001 criterion probably indicates a lack of familiarity with this organization. There may be a problem in respondent's recognition of Jemaah Islamiyah, as well, because it translates literally as "Muslim Association." 
One of the most intriguing aspects of this analysis is that respondents who identify themselves as Malay, rather than as Muslim, tend to express more favorability toward organizations and people associated with radical Islam than any of the other identity categories. For these respondents, Malay culture appears to trump their identity as Muslims, even though most respondents who identify in this way probably adhere to Islam as their religion. The data thus provide an opening insight into an existing cultural nationalism independent of the Buddhist-Muslim cleavage.

The subjective measure of identity also helps to explain several attitudes toward the Thai state. Table 9 shows, first, that a majority of Muslims are loyal to the Thai nation, in the sense of being proud to be citizens and in being willing to fight for Thailand should there be a war. In all categories, over three-fourths of all Muslims are proud to be citizens of Thailand, roughly two-thirds are willing to fight for Thailand should the necessity arise, over three-fourths would choose to be Thai citizens, and, perhaps more significantly, a substantial majority support the view that Thailand should remain one nation without part of the country allowed to become fully separate.

Having noted these findings, however, the data also indicate significant variation across subjective identifications. There are significant differences between Buddhists and Muslims on all items, but respondents who identify primarily as "Malay" appear less assimilated than Muslims in general. They are ten points lower in the measure of pride in being a citizen, only 50 percent would be willing to fight for Thailand in a war, nearly one-third support the idea of political separatism, and

\section{Table 9 Subjective Identity and Assimilation into the Thai State (in percent)}

\begin{tabular}{|c|c|c|c|c|c|}
\hline \multirow[b]{2}{*}{ Item } & \multicolumn{5}{|c|}{ Above All I Am } \\
\hline & Thai & Malay & Muslim & Buddhist & $P<$ \\
\hline Proud to be a citizen of Thailand & 99.4 & 84.4 & 94.1 & 98.0 & .000 \\
\hline $\begin{array}{l}\text { Willing to fight for Thailand in } \\
\text { a war }\end{array}$ & 83.6 & 50.0 & 67.6 & 84.1 & .000 \\
\hline $\begin{array}{l}\text { Part of the country should be } \\
\text { allowed to become fully } \\
\text { separate }\end{array}$ & 13.3 & 29.6 & 24.2 & 21.6 & .000 \\
\hline $\begin{array}{l}\text { If you had to choose, would you } \\
\text { choose citizenship as Thai, } \\
\text { Malaysian, or other? }\end{array}$ & & & & & \\
\hline Response of "Thai" & 97.1 & 79.5 & 90.3 & 97.9 & .000 \\
\hline
\end{tabular}


20.5 percent would choose a nationality other than Thai if they had to choose. The data clearly open the door for an interpretation that an important cleavage exists between adherence to cultural Malay identification and identity as Muslims.

\section{Critical Dimensions of Political and Cultural Identity in the Five Southern Provinces}

The factor analysis of selected items in the southern Thai sample also indicates five dimensions of more political and political-cultural attitudes that appear to characterize the area. ${ }^{6}$ As noted above, the first and strongest factor consists of favorable attitudes toward indicators of support for militant Islam. Factor 2 clearly organizes indicators associated with Islamic identity; Factor 3 represents trust in government, as well as trust in other people; ${ }^{7}$ Factor 4 organizes several questions related to political control of the area; and Factor 5 can be construed as measuring levels of patriotism.

Factor 4 shows that trust in military leaders is related negatively to trust in Muslim leaders, while the opposite is not the case; that is, trust in imams and tok khru is not negatively associated with trust in military leaders. Perhaps indicative of a much deeper set of attitudes, support for the emergency decrees, trust in military leaders, and negative associations with Muslim leaders are also associated with a favorable impression of the United States. ${ }^{8}$ This factor appears to align public opinion regarding the United States with efforts to control or even to suppress the insurgency. On a scale of 1 to 10 (very bad to very good) the United States scores 3.75. Appearance on this factor, with a positive sign, implies that the United States is associated with an anti-Muslim bias.

When the indicators expressed in these factors are scored as the average of indicated responses, divisions on each of the dimensions between Buddhists and Muslims become clearer. Further analysis shows expected differences between Buddhists and Muslims on all of the factors. Muslims are significantly more favorable toward insurgent groups (Factor 1), significantly more identified with Islam (Factor 2), less trusting of the society and environment that surrounds them (Factor 3), less supportive of official efforts to assert control over the region (Factor 4), and less patriotic (Factor 5).

It must also be remembered, however, that in the self-identifying question noted earlier, many Muslims identify as "Thais." In fact, 33.0 
percent of Muslim respondents indicate that they identify themselves "first of all" as "Thais." Not surprisingly, nearly half of Thai-speaking Muslims identify as "Thais," rather than as "Muslims" (44.7 percent), while only 26.2 percent of Malay-speaking Muslims identify themselves in this way. When this latter category (Muslims who identify as Thais) is added, the picture is modified even further. Table 10 shows that when the indicator of identity is used as a predictor, the level of patriotism of Muslims who see themselves as Thais ranks higher than the overall mean and is substantially higher than those who identify either as "Malay" or as "Muslim." The data also show that respondents who identify primarily as "Malay" rank considerably below "Muslim" identifiers in patriotism. This "sifting" of the data implies a definable cultural core of identity that transcends simple distinctions between Buddhists and Muslims associated with lower levels of commitment to the nation of Thailand.

\section{Cultural Identity and Political Participation}

What role does this ethnic and cultural identity play in the political life of the Deep South provinces? Clearly, one way of approaching this question is to discern political orientations associated with the various identities in Table 10. Table 11 indicates relative levels of support for democracy associated with each cultural identity. Both categories of respondents who identify as "Thais" (including Muslims who see themselves in this way) are significantly more supportive of democracy than those who identify primarily as "Buddhists," "Muslims," and "Malay." These latter categories fall below the mean in support for democracy. Those who identify as "Malay" fall even further behind than the other

\section{Table 10 Comparisons of Cultural Identification with Scores on "Patriotism" in an Analysis of Variance}

\begin{tabular}{lc}
\hline Identification & Mean Score on Patriotism Factor \\
\hline Above all I am Thai (Buddhists only) & 2.6076 \\
Above all I am Malay & 2.2233 \\
Above all I am Muslim & 2.4279 \\
Above all I am Buddhist & 2.6122 \\
Above all I am Thai (Muslims only) & 2.5664 \\
Total & 2.5131 \\
$N=1,361$ & \\
Significance of F-test $=.000$ & \\
\hline
\end{tabular}




\section{Table 11 Cultural Identification and Support for Democracy in an Analysis of Variance}

\begin{tabular}{lc}
\hline Identification & Support for Democracy Score \\
\hline Above all I am Thai (Buddhists only) & 5.0812 \\
Above all I am Malay & 3.9624 \\
Above all I am Muslim & 4.5728 \\
Above all I am Buddhist & 4.6391 \\
Above all I am Thai (Muslims only) & 4.9614 \\
Total & 4.8036 \\
Significance of F-value $=.000$ &
\end{tabular}

Note: a. The measure of Support for Democracy score is composed of mean scores on four items: (1) "Democracy is preferable to any other system"; (2) "Democracy is suitable for Thailand"; (3) "Democracy can solve our problems"; and (4) "How much do you want Thailand to be democratic, now?"

groups by a noticeable amount. It is also important to note that both "Muslim" and "Buddhist" identifiers fall well below Muslims who identify primarily as "Thai" in support for democracy, and that "Buddhist" and "Muslim" identifiers rank close together below the group mean.

A long tradition in the literature on political participation identifies a variety of indicators of this phenomenon (Verba and Nie 1972). These indicators range from the act of voting to what are often characterized as "unconventional" forms of political participation, such as demonstrations and acts of violence. One may rightly observe that honest responses to questions on acts of violence, withholding taxes, and participation in demonstrations may significantly underestimate the true activity of this type. There are, however, enough positive responses to make a consideration of these behaviors useful, plus these questions factor neatly onto a measure identified here as "unconventional political participation."

Twelve indicators factor into four discernable factors. The first is a measure of "unconventional political participation" (Factor 1). The second represents overall interest in politics, including attentiveness to news about politics (Factor 2). A third factor captures activity of respondents in conventional political participation (Factor 3), and the fourth factor simply combines two measures of participation in voting (Factor 4). When these dimensions of political participation are linked to measures of identity, additional insights emerge. First, Muslims who identify as "Thai" score at least as high on voting participation as other respondents who identify as "Thai." It is also important to note that respondents who identify as "Malay" score considerably lower on the 
measure of participation in voting. "Malay" identifiers also show considerably less interest in politics than the other groups, reinforcing a view that this group is, marginally, outside the mainstream of conventional politics. On the measure of "conventional" political activity, "Malay" identifiers are second lowest, exceeded only by "Muslim" identifiers. Muslims who identify as "Thai" score higher than any other category, suggesting a significant disparity between Muslims who identify as Thai citizens and Muslims in other categories.

Most important is the association of the identity measure with "unconventional" political behavior that includes participation in tax boycotts, demonstrations, and even violent acts for a political cause. "Malay" identifiers score the highest, by far, on this dimension. Clearly, respondents who identify themselves as "Malay," above other identifications, not only place themselves outside traditions of peaceful political discourse and action, compared to other identities, but are far above other groups in generally illegal or otherwise unsanctioned activities in the political sphere (see Table 12).

\section{Sources of Support for Radical Islam}

Karen Von Hippel (2002) addresses several theories concerning the roots of terrorism that, she says, "circulate as received wisdom." One associates terrorism with poverty and deprivation; another argues that lack of education becomes a breeding ground for terrorist movements. Both of these theories resonate with discourses concerning causes of insurgency in southern Thailand that propose ameliorative solutions to the continuing violence that are associated with "modernization theory."

Table 12 Political Participation and Cultural Identification in an Analysis of Variance

\begin{tabular}{lcccc}
\hline Identification & $\begin{array}{c}\text { Voting } \\
\text { Activity }\end{array}$ & $\begin{array}{c}\text { Political } \\
\text { Interest }\end{array}$ & $\begin{array}{c}\text { Conventional } \\
\text { Political } \\
\text { Activity }\end{array}$ & $\begin{array}{c}\text { Unconventional } \\
\text { Political } \\
\text { Activity }\end{array}$ \\
\hline Thai (Buddhists) & 2.7979 & 2.3391 & .8401 & .0594 \\
Malay & 2.5319 & 2.0556 & .8033 & .2200 \\
Muslim & 2.7476 & 2.1865 & .7666 & .0591 \\
Buddhists & 2.7083 & 2.4184 & .8299 & .0680 \\
Thai (Muslims) & 2.8019 & 2.2481 & .8407 & .1017 \\
Total & 2.7762 & 2.2534 & .8088 & .0739 \\
Significance of F-value $=.000$ & & & & \\
\hline
\end{tabular}


Von Hippel challenges these general explanations of terrorist violence by noting that the evidence does not support such interpretations. She refers to a study by Krueger and Maleckova (2002) that notes that most international terrorists are by no means poor (bin Laden, for example) and, instead, well educated, further arguing that most people become ideologically polarized through education. These controversial ideas can be tested by examining data from southern Thailand, specifically focusing on respondent attitudes toward the indicators of support for radical Islamic movements and participation in "unconventional" forms of political behavior.

Table 13 tests propositions regarding a variety of hypothesized sources of support for "radical Islam." Although "religiosity" is associated with such support, ironically, when Buddhists are eliminated from the data set, even this disappears as a cause or promotion of radical attitudes. Furthermore, radical attitudes alone do not appear to be related to unconventional political behavior, that is, protests and violence, among other activities.

When attitudes toward radical Islamic subjects are combined (multiplied) with indicators of education, sufficiency of income, religiosity, and subjective social status, however, the picture of the causes of radi-

\begin{tabular}{|c|c|c|c|c|c|c|}
\hline \multirow[b]{2}{*}{ Variables } & \multicolumn{3}{|c|}{ Buddhists and Muslims } & \multicolumn{3}{|c|}{ Muslims Only } \\
\hline & $\begin{array}{l}\text { Regression } \\
\text { Coefficient }\end{array}$ & $\beta$ & $\begin{array}{l}\text { Significance } \\
\quad \text { of } t\end{array}$ & $\begin{array}{l}\text { Regression } \\
\text { Coefficient }\end{array}$ & $\beta$ & $\begin{array}{c}\text { Significance } \\
\text { of } t\end{array}$ \\
\hline $\begin{array}{l}\text { Education } \times \\
\text { radical views }\end{array}$ & .002 & .163 & .001 & .003 & .158 & .006 \\
\hline $\begin{array}{l}\text { Religiosity } \times \\
\text { radical views }\end{array}$ & .003 & .174 & .001 & .005 & .313 & .000 \\
\hline $\begin{array}{l}\text { Income } \\
\text { sufficiency } \times \\
\text { radical views }\end{array}$ & .008 & .224 & .000 & .007 & .167 & .016 \\
\hline $\begin{array}{l}\text { Social status } \times \\
\text { radical views }\end{array}$ & -.009 & -.469 & .000 & -.012 & -.544 & .000 \\
\hline $\begin{array}{l}\text { Support for } \\
\text { democracy }\end{array}$ & -.062 & -.062 & .091 & -.014 & -.076 & .104 \\
\hline \multirow[t]{2}{*}{ Patriotism } & -.124 & -.140 & .000 & -.116 & -.135 & .004 \\
\hline & \multicolumn{3}{|c|}{$R$-squared $=.122$} & \multicolumn{3}{|c|}{$R$-squared $=.175$} \\
\hline
\end{tabular}


cal action changes dramatically. Table 13 shows how these demographic indicators, combined with scores on radical attitudes, go a long way toward explaining how respondents come to participate in radical actions. In Table 13, more education, higher levels of religiosity, and sufficiency of income all make respondents more likely to engage in radical actions, when respondents also hold radical views. Working against participation in radical actions are upper social status and patriotism. Support for democracy does not reach the threshold of a significant contributor in retarding radical actions. Subjective social status, though strong in the equation, is hardly amenable to policy measures; inculcation of patriotism, however, clearly turns citizens away from radical action against the society and the state.

Effects of education, religiosity, and income satisfaction are considerably more interesting in any case. Contrary to implications of modernization theory, participants in radical actions appear to have higher levels of satisfaction with their incomes and experience more education. As might be expected, more deeply religious respondents are more likely to have participated in "unconventional" political behaviors. Both income satisfaction and education appear to be energizing factors for sympathies with radical Islam. The role of income satisfaction in this regard is consistent with relative deprivation theory arguing that only when a population reaches a threshold beyond abject poverty can revolutionary ideologies motivate populations to political action. Von Hippel (2002, 28-30) suggests that if the length of education is solely in Koranic schools, this experience may be a breeding ground for revolutionary ideologies and radical actions, particularly of the type conducted by idealistic youth who are highly religious and converted to revolutionary agendas.

\section{Conclusion}

The analysis of data obtained from respondents in southern Thailand presents a picture at odds with much of the conventional wisdom about sentiments and society in the region. First of all, there is a fundamental unity of values between Buddhist and Muslim communities in most respects that contrasts sharply with the significant differences between the four Muslim provinces (plus Songkla) and the rest of Thailand. This similarity of views and interests between Buddhists and Muslims provides little support for the level of insurgency that characterizes the region today. One inference, of course, is that the insurgency represents 
such a small minority of the Muslim community that characterizations of the crisis as "Muslim" are distortions of the true picture. Furthermore, southern Thai Buddhists are equally, if not more, at variance with the rest of Thailand in fundamental attitudes and values. The data provide support for hypotheses that Buddhists and Muslims are not very distinguishable in terms of basic orientations to government and society. Muslims appear to be significantly more religious and more traditional, but, as noted above, these orientations do not appear to influence attitudes substantially in a negative direction. There are numerous congruencies that offer optimism for the ability of Buddhists and Muslims to live together.

Muslims and Buddhists do differ in terms of their early socialization and their experiences in interactions with government. While the more traditional and religious socialization could provide a future seedbed for political Islam, this background alone does not appear to lead to any less commitment to the security of the Thai state. More ominous is the perception by Muslims of government as more corrupt, especially at the national level rather than at the local level. The data indicate that these views are based upon experiencing more contact with corrupt officials than their Buddhist counterparts. The sharp differences between perceptions of local and national government pose a somewhat strained environment under circumstances where government emanates from the national level, which, of course, includes efforts to resolve conflicts by forces that are not indigenous to the area. The heart of the matter here is the policy of the Ministry of the Interior to govern from the center, without sufficient sensitivity to attitudes and opinions at the local level. ${ }^{9}$ The problem has been exacerbated by a long-standing policy in the past of sending to the South civil servants who have not performed well in other areas of the country as a kind of punishment for past failures.

Buddhists and Muslims differ dramatically in terms of their political orientations and their attentiveness to politics. Muslim respondents in the survey are located at significantly lower levels of socioeconomic status, as measured by income and education. Although, in general, higher socioeconomic status is associated with higher levels of political knowledge and attentiveness, Muslims apparently compensate for the deficit in education so that they demonstrate equal or sometimes even higher levels of political participation than do Buddhists. One explanation for this is the difference in social patterns between the wat and the mosque. The result is that Muslims rely significantly more on personal contacts, while Buddhists rely almost totally on political in- 
formation from television. In this respect, Muslims and Buddhists live in fundamentally different worlds.

These differences lead to significant cleavages in adherence to political party identifications. Buddhists are totally committed to the Prachadhipat Party, especially in the Malay-speaking provinces, where their allegiance is virtually 100 percent. Muslims appear committed somewhat more to "other parties," even including Thai Rak Thai. In the non-Malay-speaking areas, however, such as Satun, Muslims are more like Buddhists in their support of Prachadhipat. This finding reaffirms previous research that shows significant political cleavages between Thai-speaking and Malay-speaking Muslims, and reinforces the perception that major sources of political factionalism are less religiously based than that they originate in ethnic identities that have characterized southern Thailand for centuries.

Finally, the data offer lessons for Thais above the Isthmus of Kra, as well as foreign scholars, journalists, and social researchers who report on politics and society in the South. First, the insurgencies are not a phenomenon of the "border provinces"; Pattani is not on the border with Malaysia, nor is Satun, a border province, characterized by insurgencies. Even more important is the recognition that Jawi is not a language spoken by southern Thai Muslims. Jawi is not, technically, a spoken language and Muslims in the non-Malay-speaking provinces speak Thai, not Jawi or even Malay. General references to "Muslims" distort the cultural reality of what is taking place there.

Above all, traditional ways of thinking about southern Thai Muslims need to be turned on their head. Thai-speaking Muslims are very different in many respects from Malay-speaking Muslims. The former are more assimilated, but overall levels of patriotism and identification as "Thais" include large majorities of both cultural traditions. Over one-third of religious Muslims identify "above all" as "Thais." Over two-thirds of all Muslims would fight for Thailand and even more are proud to be Thais. Of Muslims who identify primarily as "Malay," however, only half would be willing to fight for Thailand, but these are not citizens for whom "Muslim" is a primary identification and they constitute only about 2.6 percent of the population in the five southern provinces.

Most important of all, however, is the need for sensitivity to the life and culture of the peoples of Narathiwat, Pattani, Yala, and even Satun and Songkla. Any serious effort at unification and resolution of the conflicts in southern Thailand requires an acknowledgment that Thais who live in the region, both Buddhist and Muslim, including Malay-speaking 
and Thai-speaking Muslims, are overwhelmingly loyal fellow-citizens. Non-Muslim Thais need to become aware of the ethnic diversity of the region, as well as the importance of cultural markers conveyed by uses of Thai or Malay as the language of the home. Non-Muslims need to become sensitive to the importance of sharia as a religious commitment for many Muslims, as well as a political one.

Finally, southern Thai Muslims-especially Malay-speakers-need to be recognized as holding equal citizenship with Buddhists in the nation of Thailand. Above all, they are not khaeck (that is, "visitor" or "alien") and this term should lose its currency, especially its use by civil servants, as it is imbued with racist connotations. The only hope for future resolution of ethnic-based conflicts in the nation is a recognition that, in the final analysis, as a Muslim once said to me, "We are all Thai."

What can be done to curb the violence in southern Thailand? Respect for the local culture is clearly one avenue of opportunity, but this will require a greater commitment to decentralization of government and administration, a solution likely to be rejected by Buddhists in the area. The data from this study suggest that modernization strategies, such as education, are not likely to have a substantial impact in quelling the violence that (to use the title of Duncan McCargo's 2008 prize-winning book about the region) is "tearing apart the land." Perhaps a beginning would be to listen to voices from the region, a strategy proposed by the National Reconciliation Commission but rejected by successive governments. The future of the region appears bleak until territorial claims on the region for cultural assimilation decline. There does not appear to be much sentiment above the Isthmus of Kra for moving in this direction.

Robert B. Albritton is professor of political science at the University of Mississippi. He has received Fulbright awards to Prince of Songkla University (1989) and Chiangmai University (1994). In 2000, he received an honorary degree from Prince of Songkla University. Since 2000, he has been associated with the King Prajadhipok's Institute in studies of democracy in Thailand, and he is a member of the Asian Barometer Project.

\section{Notes}

Funding for data collection came from the Asian Barometer Project (Academica Sinica and National Taiwan University) and a grant from the US Institute for Peace, SG-079-04F. 
1. The Malay culture of the deep southern Thai provinces and those of northern Malaysia share an older culture that differs from standard Malaysian Malay culture in spoken language and the use of Jawi, a form of the Malay language written in Arabic script.

2. McCargo (2008) acknowledges some merit to this explanation, but is reluctant to accept the full implications of this interpretation.

3. This notion was tested in a regression equation with dummy variables representing provinces and language of the home. Obviously, there is a great deal of collinearity in that Satun and Songkla are predominantly Thai-speaking, while Narathiwat, Pattani, and Yala are predominantly Malay-speaking among Muslims. This collinearity is apportioned by the regression, and the results show that, in assessing radical Islamic groups favorably or unfavorably, location of respondents by province (or changwat) had no significant impacts, while language of the home proved highly significant for differentiating respondents on this dimension.

4. The national sample included, of course, some representation from the southern area. It included 105 respondents from two provinces (Songkla and Narathiwat). These respondents have been omitted from the national sample for purposes of comparison, thereby eliminating redundancy across the two samples. The "rest of Thailand" includes Ranong, Phang-Nga, Trang, and Nakorn Sri Thammarat, so the comparison is between the Deep South and the rest of Thailand that includes provinces from the "upper South."

5. Slightly over 1,100 respondents expressed some degree of familiarity with Osama bin Laden, the most of any item.

6. The factor analysis, with orthogonal rotation, implies that each of the factors is totally independent of all the others.

7. It is important to note that this factor includes trust in Buddhist monks, but not imams and tok khru; the latter load on the factor representing Islamic identity.

8. A measure of impressions of the United States was included because of frequent references to negative evaluations of the United States by Muslims (Simon and Benjamin 2001).

9. The author was in Pattani when Prem Tinsulanonda came to the CS Thani hotel to proclaim that the use of Malay or Jawi would not be permitted in the Malay-speaking provinces. Copies of his statement were immediately distributed by radical groups to document the perception that the capital was insensitive to cultural orientations of the region.

\section{References}

Abuza, Zachary. 2003. Militant Islam in Southeast Asia: Crucible of Terror. Boulder, CO: Lynne Rienner Publishers, 2003.

Aeosrivongse, Nithi. 2005. "Understanding the Situation in the South as a 'Millenarian Revolt."' Kyoto Review (March). http://kyoto review.cseas .kyoto-u.ac.jp/issue/issue5/article380. 
Albritton, Robert B., and Sidhinat Prabudhanitisarn. 1997. "Culture, Region, and Thai Political Diversity." Asian Studies Review 21: 61-82.

Albritton, Robert B., Phan-ngam Gothamasan, Noree Jaisai, Manop Jitpoosa, Sunandpattira Nilchang, and Arin Sa-idi. 1996. "Electoral Participation by Southern Thai Buddhists and Muslims." South East Asia Research 4: $127-156$.

Arjomand, S. 1995. "Unity and Diversity in Islamic Fundamentalism." In Fundamentalism Comprehended, ed. Martin Marty and R. S. Appleby. Chicago: University of Chicago Press.

Askew, Marc. 2007. Conspiracy Politics and a Disorderly Border: The Struggle to Comprehend Insurgency in Thailand's Deep South. Washington, DC: East-West Center.

Jitpiromsri, Srisompob, and Panyasak Sobhonvasu. 2005. "Quandary of the Deep South's Conflicts: Structural or Ideological Determinants.” Unpublished paper presented at the International Conference on Thai Studies, DeKalb, IL.

Komin, Suntaree. 1991. Psychology of the Thai People: Values and Behavioral Patterns. Bangkok: National Institute of Development Administration.

Krueger, Alan B., and Jitka Maleckova. 2002. "Education, Poverty, Political Violence, and Terrorism: Is There a Causal Connection?" Charles University, Working Papers, Research Program in Developmental Studies, Woodrow Wilson School, Princeton University, May 2002, 1-16.

McCargo, Duncan. 2008. Tearing Apart the Land: Islam and Legitimacy in Southern Thailand. Ithaca, NY: Cornell University Press.

2009a. "Thai Buddhism, Thai Buddhists, and the Southern Conflict." Journal of Southeast Asian Studies 40, 1: 1-10.

- 2009b. "The Politics of Buddhist Identity in Thailand's Deep South: The Demise of Civil Religion." Journal of Southeast Asian Studies 40, 1: $11-32$.

Mishler, William, and Richard Rose. 2001. "What Are the Origins of Political Trust? Testing Institutional and Cultural Theories in Post-Communist Societies." Comparative Political Studies 34: 30-62.

Satha-Anand, Chaiwat. 2005. "The Silence of the Bullet Monument: Violence and 'Truth' Management, Dusun-nyor 1948 and 'Kru-Ze' 2004.' Keynote address at the International Conference on Thai Studies, DeKalb, IL.

Simon, Steven, and Daniel Benjamin. 2001. "The Terror." Survival 43, 4: 5-18.

Syukri, Ibrahim. 2005. History of the Malay Kingdom of Patani. Bangkok: Silkworm Books.

Tessler, Mark. 2002. "Islam and Democracy in the Middle East: The Impact of Religious Orientations on Attitudes Toward Democracy in Four Arab Countries." Comparative Politics 34: 337-354.

Verba, Sidney, and Norman Nie. 1972. Political Participation in America: Political Democracy and Social Equality. New York: Harper and Row.

Von Hippel, Karen. 2002. "The Roots of Terrorism: Probing the Myths." The Political Quarterly 73, Supplemental: 25-39. 